\section{Høy dødelighet blant nyfødte i Pakistan}

Forskere har funnet en overraskende høy dødelighet blant nyfødte i en urban befolkning i Pakistan med god tilgang til helsetjenester (1). Ifølge Imtiaz Jehan og kolleger tyder resultatene på at bedre kvalitet på helsetjenester er avgjørende for å redusere neonatal dødelighet.

Studien var basert på 1280 fødsler i Latifabad, Hyderabad i Pakistan i perioden 2003-05. De første 28 levedager var mortalitetsraten 47,3 per 1000 levendefødte barn. Perinatal mortalitetsrate (dødfødte og dødsfall de første 28 dagene) var hele 82,5 per 1000 fødsler. For tidlig fødsel, keisersnitt og komplikasjoner under fødselen var assosiert med dødelighet blant de nyfødte. Det ble utført keisersnitt hos $19 \%$, noe som er høyere enn hva FN anbefaler (5-15\%).

Rundt $45 \%$ av dødsfallene skjedde innen 48 timer og $73 \%$ i løpet av den første uken. Verken fødsel i en helsefasilitet eller fødsel med helsepersonell til stede var assosiert med færre dødsfall. Nesten alle ( $88 \%$ ) nyfødte som døde, fikk behandling, og hele $75 \%$ døde i sykehus.

Pakistan har en av de høyest rapporterte mortalitetsratene i verden blant nyfødte -49 per 1000 levendefødte. Forfatterne hadde forventet en signifikant lavere mortalitetsrate i denne studien, der de fleste hadde god tilgang til helsetjenester.

- Vi tror det er to årsaker til dette. For det første mistenker vi at Pakistans mortalitetsrate egentlig er mye høyere enn angitt på grunn av underrapportering. Og til tross for tilsynelatende god tilgang til helsetjenester, kan det være at kvaliteten på disse ikke er optimal, sier Jehan.

\section{Oda Riska}

oriska@hotmail.com

Tidsskriftet

\section{Oppgitte interessekonflikter: Ingen}

\section{Litteratur}

1. Jehan I, Harris H, Salat S et al. Neonatal mortality, risk factor and causes: a prospective population-based cohort study in urban Pakistan. Bull World Health Organ 2009; 87: $130-8$.

\title{
Ufrivillig seksuell erfaring blant unge
}

\author{
Seksuell vold forekommer i alle land, men de fleste internasjonale \\ studier er utført i Vesten og omfatter i hovedsak vold rettet mot gifte \\ kvinner. Seksuell utnytting av barn er blitt et aktuelt tema, mens sek- \\ suell vold som utøves mellom unge mennesker er viet liten interesse.
}

- Det er forsket lite på ufrivillige seksuelle forhold blant unge i lavinntektsland, sier seniorforsker Shireen Jejeebhoy ved Population Council i New Dehli.

Denne internasjonale organisasjonen arbeider med reproduktiv helse, og Jejeebhoy arbeider med ungdomshelse og spesielt med forebygging av aborter. Hun har vært engasjert som forsker i seksuell og reproduktiv helse ved Verdens helseorganisasjon (WHO) i Genève, har redigert en bok om ufrivillig seksuell erfaring blant unge i lavinntektsland (1) og er nå med på en større studie om ungdomshelse i seks delstater i India. Jeg traff henne på en kongress i internasjonal medisin i Amsterdam i 2007, der hun foreleste om ufrivillig seksualitet blant unge. I sitt arbeid med ungdomshelse i hjembyen ble hun overrasket over at mange unge rapporterte at de hadde følt seg tvunget til å innlede et seksuelt forhold.

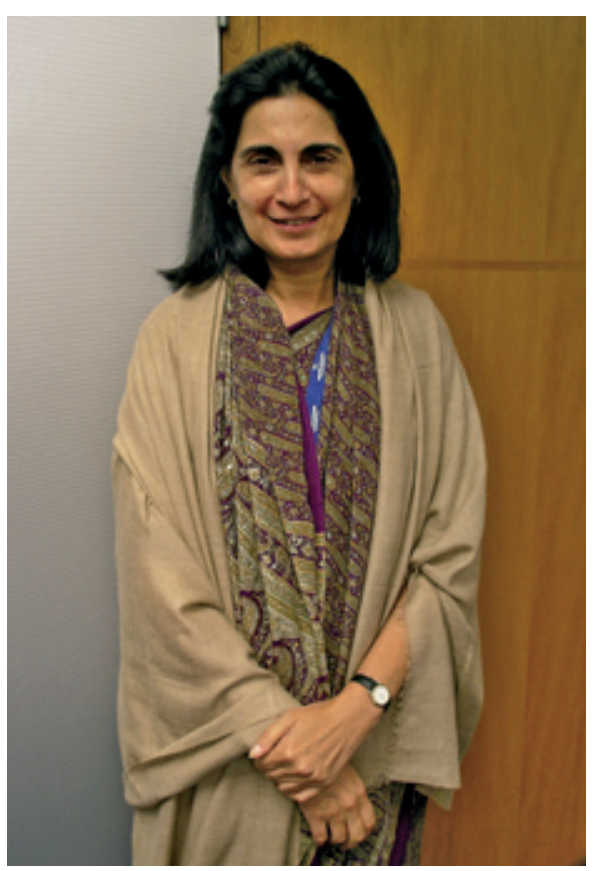

Shireen Jejeebhoy er seniorforsker ved Population Council i New Dehli. Foto Berit Rostad

\section{Ufrivillig sex}

Ufrivillig sex inngår i WHOs definisjon av seksuell vold som omfatter enhver seksuell handling og forsøk på å oppnå en seksuell handling ved bruk av tvang, uønskede seksuelle kommentarer og tilnærmelser mot en person uavhengig av relasjon til personen (2).

I sitt arbeid med unge hadde Jejeebhoy tatt for gitt at seksuell kontakt med en partner var både frivillig og ønsket. Virkeligheten var en annen. Hun stilte seg spørsmålet: hva betyr en slik erfaring for de unges fysiske og mentale helse?

- Jeg søkte i faglitteratur på Internett, men fant svært lite beskrevet om unge i lavinntektsland. Studier var fra vestlige land, og mest om ufrivillig seksualitet innen ekteskapet. Det var få studier fra land i Asia, Latin-Amerika og Afrika.

- Hva fant du av studier fra ikke-vestlige land?

- Forskningsresultatene fra de ulike landene var samstemte. Unge kvinner hadde en større risiko for uønskede seksuelle erfaringer. Kvinners første seksuelle erfaring var ofte koblet til fysisk makt, trusler, svik eller at kvinnen ble lurt. Spesielt i land med arrangerte ekteskap var dette vanlig. Det var en venn, bekjent eller en autoritetsfigur, som et familiemedlem eller en lærer, som tvang kvinnen til sex. En studie i India fra 2005 har vist det samme, at seksuell tvang utføres av et familiemedlem eller en lærer, sier Jejeebhoy.

- Er det noen fellestrekk hos de unge som hadde slike erfaringer?

- Ja. Ifølge disse studiene og egen arbeidserfaring er det flere faktorer som påvirker risikoen for uønsket sex, som manglende selvhevdelse og usikkerhet om hvordan man skal forholde seg, siden seksualitet er noe man ikke snakker om. Det er liten eller ingen oppmerksomhet om temaet i skole og helsesektor. Sosiokulturelle faktorer spiller en rolle idet det er maktubalanse mellom kjønnene. Unge menn mener de har rett til sex, og de tar avgjørelsen om seksuell kontakt. Hvis de i etterkant blir 